\title{
Effects of sewage sludge biosolid amendments on the potential of maize (Zea mays L.) in phytoremediation of trace metals in chromated copper arsenate contaminated soils
}

\author{
Caroline Kiwanuka Nakiguli ${ }^{\text {a,b,c* }}$, Timothy Omara ${ }^{\text {b,c,d }}$ and Emmanuel Ntambi ${ }^{\text {a }}$ \\ ${ }^{a}$ Chemistry Department, Faculty of Science, Mbarara University of Science and Technology, P.O. \\ Box 1410, Mbarara, Uganda. \\ ${ }^{\mathrm{b}}$ Department of Chemistry and Biochemistry, School of Sciences and Aerospace Studies, Moi \\ University, P.O. Box 3900, Eldoret, Kenya. \\ ${ }^{\mathrm{c}}$ Africa Center of Excellence II in Phytochemicals, Textiles and Renewable Energy, Moi University, \\ P.O. Box 3900, Eldoret, Kenya. \\ ${ }^{\mathrm{d}}$ Department of Quality Control and Quality Assurance, Product Development Directory, \\ AgroWays Uganda Limited, Plot 34-60, Kyabazinga Way, P.O. Box 1924, Jinja, Uganda. \\ carolkiwanuka@gmail.com,cnakiguli@must.ac.ug
}

Keywords: Bioaccumulation factor, integrated pollution index, phytoextraction, translocation factor.

The effect of sewage sludge amendment $(5-25 \% \mathrm{w} / \mathrm{w})$ on the potential of maize (MM3 variety) to phytoextract trace metals from chromated copper arsenate (CCA) contaminated soils was investigated. The metal content of fresh soils, and soils, maize roots and shoots after 80 days of planting were determined by atomic absorption spectroscopy. The concentrations of chromium, copper and arsenic in fresh CCA soils were $365.8 \pm 6.18,109.72 \pm 14.04$ and $28.22 \pm 3.8 \mathrm{mg} / \mathrm{kg}$ respectively. The MM3 maize variety could be used to phytoextract or phytostabilize the trace metals in the CCA contaminated soils without or with 5-25\% sewage sludge amendment.

\section{Introduction}

Wood is one of the oldest building materials known in human history. It is used in different parts of the world for various structural applications [1]. In Africa, the use of wood is connected to its availability and it being cheap as compared to other construction materials. In comparison to metals, glass and plastics, wood is an exceptionally versatile material, requires little energy across its life cycle, present lighter carbon footprint, are easy to finish and have higher insulation rating [2]. The dynamic nature of the building environment in Uganda poised by high population growth, urban agriculture and massive industrialization has led to a rise in the demand for wood [3, 4]. Consequently, many unregulated industries have sprung up in Ugandan wood industry, leaving several 
environmental footprints [5-7]. Because of its susceptibility to attack by insects, wood is often preserved using chemicals $[8,9]$. However, the inadvertent use of preservatives such as chromated copper arsenate (CCA), creosote and other nascent copper-based formulations to prolong the life of lumber present environmental concerns because they contain heavy metals and polycyclic aromatic hydrocarbons which are toxic to humans [9-12]. CCA contain arsenic in the inorganic pentavalent form $[13,14]$ which act as an insecticide while copper is present as $\mathrm{Cu}$ (II) to protect the wood from fungi [12]. Chromium on the other hand occurs in the trivalent form [15] and is responsible for fixing copper and arsenic complexes such as chromium (III) arsenate or chromium dimerarsenic clusters [16] into the structures of lignin, cellulose or hemicellulose of the wood $[17,18]$.

The use of CCA for wood treatment has been banned in many countries, though this has not been fully implemented in some developing countries like Uganda. In countries where it has been banned, some structures built using CCA treated wood are still in existence, and leach CCA into the immediate environment, causing heavy metal pollution [19, 20]. For this reason, remediation of such contaminated soils are still required to reduce the risk of exposure to the heavy metals by humans. In continuity of our previous studies [7,21], we evaluated the effect of sewage sludge amendment on the phytoremediation potential of maize in cleaning up CCA contaminated soils. Exposure to arsenic in CCA leads to vomiting, discomfort, abdominal pain, bloody diarrhoea and in chronic cases may induce cancer in humans. Exposure to hexavalent chromium is known to cause skin irritation and lung cancer $[22,23]$.

\section{Experimental part}

\section{Soil sampling and analysis}

Random aggregate soil samples (50 kg in total) were collected from Kitetika Wood Treatment Factory (coordinates 0.4030814 and 32.585174 ) in Kitetika village, Nangabo Sub-county, Wakiso district of Uganda using plastic spades at depths of $0-15 \mathrm{~cm}$. The composite samples were thoroughly mixed to give the final sample which was subsequently packed into air-tight polythene bags. Sewage sludge biosolid (50 kg) was obtained in clean polythene bags from National Water and Sewerage Corporation Plant situated in Bugolobi, Kampala, Uganda.

All the samples were transported to the Chemistry Laboratory of Mbarara University of Science and Technology, Mbarara, Uganda. Stones, plant tissues, pebbles and rock particles were removed from the samples which were allowed to dry at room temperature on clean polyethene sheets. The dried samples were subsequently ground and sieved through $2 \mathrm{~mm}$ stainless steel sieves, packed in air-tight plastic bags and stored at room temperature until commencement of analysis [7]. Maize grain (variety MM3) for this experiment were purchased from Farm Inputs Care Centre Limited 
(FICA Seeds Limited), Plot 40/41, Bombo road, Kawempe, Kampala (Uganda).

Both CCA contaminated soils and sewage sludge biosolid samples were subjected to physicochemical analysis for $\mathrm{pH}$, nitrogen, organic matter, organic carbon, manganese, phosphorous, sand, clay, silt, cation exchange capacity (CEC) following previously used methods $[7,24,25]$.

Sewage sludge application and pot experiments

Composted sewage sludge biosolid (SSB) was added to $1 \mathrm{~kg}$ of CCA contaminated soils at 5, 10, 15, 20 and 25\% (w/w) and each was replicated thrice. The mixtures were put in 2 litre plastic containers and these were watered with double distilled water to the soil water holding capacity. Control soils were set up without any amendment. The containers were left at room temperature $\left(25^{\circ} \mathrm{C}\right)$ for two weeks for the soils to stabilize with intermittent mixing. After two weeks (14 days), soil samples (5 g) were obtained from each container and subjected to physicochemical analysis [7, 21, 24, 25].

Maize grains were soaked in water for 5 hours and six viable ones were sown in each container. Watering was done with double distilled water when necessary and hand weeding was used to keep the plants free of weeds. The experiments were maintained in a screen house at $27-28^{\circ} \mathrm{C}$ to preclude any aerial deposition of heavy metals on the soil surfaces. Three maize plants were uprooted from the potted soils after 80 days of growth (MM3 maize variety takes 80 to 90 days to reach full maturity). The shoots were separated from the roots by cutting at $0.5 \mathrm{~cm}$ above the roots. These were washed thoroughly with double distilled water, dried at $70{ }^{\circ} \mathrm{C}$ for three days and separately pulverized [7].

Heavy metal analysis and soil pollution levels

Aliquots $(1.00 \mathrm{~g})$ of pulverized root and shoot samples were digested separately with $6 \mathrm{ml}$ of a 1:1 mixture of concentrated nitric and perchloric acids. The resulting solutions were filtered into $50 \mathrm{ml}$ volumetric flasks and topped up to the mark with double distilled water. Soil samples $(1.00 \mathrm{~g})$ on the other hand were digested using 5 $\mathrm{ml}$ of a mixture of aqua regia $(3: 1 \mathrm{v} / \mathrm{v}$ concentrated nitric acid: concentrated hydrochloric) and $1 \mathrm{ml}$ of perchloric acid in 250 $\mathrm{ml}$ conical flasks. The samples were digested on a heating digester until white fumes of perchloric acid appeared. The solutions were cooled and subsequently filtered into $50 \mathrm{ml}$ volumetric flasks and made to the mark with distilled water [26]. A $20 \%$ blank prepared using $15 \mathrm{ml}$ of $63 \%$ nitric acid (Sigma Aldrich) and $5 \mathrm{ml}$ of $98 \%$ sulphuric acid was first run to remove any traces of background interferences that would otherwise cause inaccuracy of results. All the samples were analyzed for $\mathrm{Cr}, \mathrm{Cu}$ and As using AA 6300 Shimadzu double beam atomic absorption spectrophotometer (Shimadzu Corporation, Japan) at Directorate of Government Analytical Laboratory, Kampala, 
Uganda. Analyses, including five sets of standards for each metal were run in triplicate and the absorbances were used to compute the concentrations of the metals from the standard curves [27]. The results in $\mathrm{mg} / \mathrm{L}$ from the instrument were converted to the standard unit $(\mathrm{mg} / \mathrm{kg})$ for easy comparison with the set international compliance guidelines [28, 29].

To classify heavy metal pollution levels in the soils, the pollution index (PI) and the integrated pollution index (IPI) were calculated as described by Chen et al. [30]. The PI, is defined as the ratio of the metal concentration in the soil to the background concentration whereas the IPI was estimated as the mean value of PI [20]. The mean concentrations of $\mathrm{Cr}(68 \mathrm{mg} / \mathrm{kg}), \mathrm{Cu}(22$ $\mathrm{mg} / \mathrm{kg})$ and As $(5 \mathrm{mg} / \mathrm{kg})$ in non-contaminated soils collected worldwide were used as the background levels [31, 32] as employed by previous authors [20].

\section{Phytoremediation efficiency}

The translocation factor (TF) and bioaccumulation factor (BAF) were calculated to assess the heavy metal phytoextraction efficiency of the maize plants. While TF assessed the capacity of the plants to transfer the trace metals from the roots to the shoots, BAF provided an index of the ability of the shoots and roots to accumulate the metals with respect to the respective metal concentrations in the soils [20]. The indices were calculated accordingly using Equations 1-3 [33, 34].

$$
\mathrm{BAF}_{\text {shoot }}=\frac{\text { Heavy metal concentration in the shoot }}{\text { Heavy metal concentration in the soil }}
$$

$\mathrm{BAF}_{\text {root }}=\frac{\text { Heavy metal concentration in the roots }}{\text { Heavy metal concentration in the soil }}$

$$
\mathrm{TF}=\frac{\text { Heavy metal concentration in the sho }}{\text { Heavy metal concentration in the roots }}
$$

\section{Quality control and quality assurance}

All the reagents used in this study were of high analytical purity. All the volumetric ware used were soaked in 5\% nitric acid overnight and rinsed with double distilled water. Standard solutions were prepared, and these were used for calibration and quality assurance for each of the analytical batch. Quality control was performed with spiked samples analyzed once for every 10 samples. Recovery percentages from the spiked samples ranged from $96.8 \%$ to $103 \%$. Method detection limits with reagent blanks were calculated and these were $1.60,0.50$ and 0.90 $\mathrm{mg} / \mathrm{kg}$ for $\mathrm{Cr}, \mathrm{Cu}$ and $\mathrm{As}$ respectively. Analytical, equipment and filtration blanks were determined throughout the analyses, and subtractions were used to correct the heavy metal concentrations obtained. All samples were analyzed in triplicate.

\section{Statistical analysis}

All quantitative data, unless otherwise stated, were presented as means with errors represented by standard deviations attached. Significant differences between means of the investigated parameters were determined by one way ANOVA and separated using Turkey pairwise test. The analyses were ran using Minitab 
statistical software (Release 17, Minitab Inc., USA) with statistical significance set at $\propto=0.05$.

\section{Results and discussion}

\section{Physicochemical characteristics of CCA}

contaminated soils and sewage sludge biosolid

Physicochemical properties of soils influence metal speciation, mobility, bioavailability and toxicity in them. In this study, the $\mathrm{pH}$ of both CCA contaminated soils $(6.77 \pm 0.11)$ and SSB $(6.64 \pm 0.50)$ were near neutral (Table 1) and such $\mathrm{pH}$ enhances availability of cations for plant growth but these may not be phytotoxic [35]. Kim et al. [19], Tsetimi and Okieimen [36] recorded $\mathrm{pH}$ in the range of $5.90 \pm 0.10$ to $6.10 \pm$ 0.20 and $5.92 \pm 0.10$ respectively for soils from CCA contaminated sites. The slight differences in the $\mathrm{pH}$ of CCA contaminated soils to those previously reported may be due to natural processes such as the rate of decomposition of organic matter and leaching of cations, and the differences in their cation exchange capacities. Lower CEC of soils are known to lead to increase in soil $\mathrm{pH}$ [37]. Thus, the higher $\mathrm{pH}$ recorded could be due to soil factors as CCA is often applied as a water-based mixture of $0.6-6.0 \%$ (w/w) chromic acid, copper oxide and arsenic acid with $\mathrm{pH}$ between 1.6 to 2.5 [22].

The organic matter content of CCA contaminated soils and SSB were $4.40 \pm 0.08 \%$ and $17.80 \pm$ $1.50 \%$ respectively. Similarly, organic carbon recorded were $2.50 \pm 0.04 \%$ for fresh $\mathrm{CCA}$ contaminated soils and $10.3 \pm 0.06 \%$ for SSB.
These significant differences $(p \leq 0.05)$ are explained by the fact that SSB is a 50:50 mixture of organic and inorganic materials $[35,38]$.

Table 1: Physicochemical characteristics of fresh CCA contaminated soils and sewage sludge biosolid.

\begin{tabular}{|l|l|l|}
\hline Parameter & CCACS & Sewage Sludge \\
\hline $\mathrm{pH}$ & $6.77 \pm 0.11$ & $6.64 \pm 0.50$ \\
\hline Organic matter (\%) & $4.40 \pm 0.08$ & $17.80 \pm 0.26$ \\
\hline Organic carbon $(\%)$ & $2.50 \pm 0.04$ & $10.30 \pm 0.06$ \\
\hline CEC (meq $/ 100 \mathrm{~g})$ & $6.80 \pm 0.32$ & $14.70 \pm 0.11$ \\
\hline Nitrogen $(\%)$ & $0.10 \pm 0.01$ & $0.32 \pm 0.01$ \\
\hline Phosphorous $(\mathrm{mg} / \mathrm{kg})$ & $20.95 \pm 0.17$ & $166.90 \pm 1.04$ \\
\hline Manganese $(\mathrm{mg} / \mathrm{kg})$ & $94.00 \pm 0.61$ & $68.80 \pm 0.22$ \\
\hline$\%$ Sand & $72.00 \pm 0.08$ & $51.00 \pm 0.06$ \\
\hline$\%$ Clay & $19.00 \pm 0.33$ & $15.00 \pm 0.11$ \\
\hline$\%$ Silt & $9.00 \pm 0.24$ & $34.00 \pm 0.51$ \\
\hline Chromium $(\mathrm{mg} / \mathrm{kg})$ & $365.80 \pm 6.18$ & $35.00 \pm 1.06$ \\
\hline Copper $(\mathrm{mg} / \mathrm{kg})$ & $109.72 \pm 14.04$ & $1.00 \pm 0.01$ \\
\hline Arsenic $(\mathrm{mg} / \mathrm{kg})$ & $28.22 \pm 3.80$ & $\mathrm{BDL}$ \\
\hline
\end{tabular}

BDL: Below method detection limit, CCCAS: chromated copper arsenate contaminated soils. Organic matter is different from organic carbon because it includes all the other elements such as hydrogen, oxygen, nitrogen, water and other nutrients [39].

In this study, there was a significant difference $(p$ $\leq 0.05)$ in the CEC of CCA contaminated soils $(6.80 \pm 0.32 \mathrm{meq} / 100 \mathrm{~g})$ and that of SSB $(14.70 \pm$ $0.11 \mathrm{meq} / 100 \mathrm{~g})$. This could be due to the abundant cations in SSB than in the CCA contaminated soils. SSB had $166.90 \pm 1.04$ $\mathrm{mg} / \mathrm{kg}$ of phosphorous which was higher than in CCA contaminated soils while the reverse was true for manganese. These could be due to the heterogenous nature of SSB compared to CCA contaminated soils.

On the other hand, the soils had relatively higher percentage of sand $(72 \%)$ and clay (19\%) than SSB (51\% and 15\% respectively). Thus, the soils had a sandy-loam soil texture. Sandy soils 
depend heavily on the high CEC of organic matter for the retention of nutrients in the topsoil. The heavy metal content of the CCA contaminated soils were $365.80 \pm 6.18,109.72 \pm$ 14.04 and $28.22 \pm 3.80 \mathrm{mg} / \mathrm{kg}$ for $\mathrm{Cr}, \mathrm{Cu}$ and $\mathrm{As}$ respectively. SSB had lower concentrations of the heavy metals. Interestingly, arsenic was below detection limit of $0.90 \mathrm{mg} / \mathrm{kg}$ in SSB. Higher concentrations of heavy metals in CCA contaminated soils are always expected because CCA used to treat lumber contain $\mathrm{Cr}, \mathrm{Cu}$ and $\mathrm{As}$ [22]. In this study, the higher concentrations of the trace metals in the soils than in SSB could have been due to initial leaching of the metals from treated wood [19, 40-44]. There are three types of CCA (designated as A, B and C types) and the most popular is type $\mathrm{C}$, chemically made up of about $47.5 \% \mathrm{CrO}_{3}, 18.5 \% \mathrm{CuO}$ and $35.0 \%$ $\mathrm{As}_{2} \mathrm{O}_{5}$ [43]. The low concentration of arsenic recorded in CCA contaminated soils was previously reported elsewhere [36] but is not concordant with some preceding observations in which it recorded the highest concentration [19, 45]. It was previously reiterated that although chromium in CCA contaminated matrices may be converted to the more toxic hexavalent form under the influence of chemical oxidants, the amount of arsenic released is expected to be 30 to 40 times greater than the amount of hexavalent chromium released [46]. For this reason, arsenic should always remain the dominant element in terms of potential toxic impacts [46]. The levels of arsenic in the soils may have been lower than that of $\mathrm{Cr}$ and $\mathrm{Cu}$ because most of the original arsenic was fixed and then bound to the wood and/or may have undergone vertical and horizontal migration into the neighbouring soils [20]. On the whole, the concentrations of $\mathrm{Cr}$ and $\mathrm{Cu}$ were above the maximum permissible guidelines of $200 \mathrm{mg} / \mathrm{kg}$ and $50 \mathrm{mg} / \mathrm{kg}$, while arsenic concentration was less than the $50 \mathrm{mg} / \mathrm{kg}$ maximum guideline permitted in agricultural soils $[47,48]$.

\section{Soil heavy metal pollution levels}

There are many indices used to assess heavy metal pollution levels in soils. In the current study, the PI and the IPI were calculated to estimate the metal contamination levels in the CCA contaminated soils. The PI is classified into three contamination levels of low (PI $\leq 1)$, moderate $(1<\mathrm{PI}<3)$ and high $(\mathrm{PI} \geq 3)$. Our computation (Table 2) indicated that all the PI values for the heavy metals did not vary significantly and belonged to the same category of high (PI ranged from 4.99 to 5.64). On the other hand, the IPI is classified as low (IPI $\leq 1)$, middle $(1<$ IPI $<2)$ or high $($ IPI $>2)$ [30]. Thus, the IP and IPI calculated indicated that there is serious heavy metal pollution of soils at Kitetika Wood Treatment Factory.

Table 2: Pollution indices of the CCA contaminated soils.

\begin{tabular}{|c|c|c|}
\hline Heavy metal & $\begin{array}{c}\text { Pollution } \\
\text { Index }\end{array}$ & $\begin{array}{l}\text { Integrated Pollution } \\
\text { Index }\end{array}$ \\
\hline Chromium & 5.38 & \\
\hline Copper & 4.99 & \multirow{2}{*}{5.34} \\
\hline Arsenic & 5.64 & \\
\hline
\end{tabular}


Physicochemical characteristics of the unamended and amended soils

The properties of the potted control and CCA contaminated soils after 14 days of amendment with SSB are given in Table 3. The amended soils recorded increment in nearly all the physicochemical parameters unlike the unamended soils. For example, $\mathrm{pH}$ first reduced to $6.35 \pm 0.02$ with $5 \%$ amendment and then increased upto $6.99 \pm 0.18$ at $25 \%$ amendment. Soil $\mathrm{pH}$ controls the solubility and hydrolysis of metal salts, ion pair formation, surface charge of manganese, iron and aluminium oxides, organic matter and clay [49] as well as metal uptake into plant roots which is usually metal specific [50].

Table 3. Characteristics of soils after 14 days amendment

\begin{tabular}{|c|c|c|c|c|c|c|}
\hline Parameter & Control & $5 \%$ & $10 \%$ & $15 \%$ & $20 \%$ & $25 \%$ \\
\hline $\mathrm{pH}$ & $\begin{array}{ll}6.12 & \pm \\
0.11 & \end{array}$ & $\begin{array}{l}6.35 \\
\pm \\
0.02\end{array}$ & $\begin{array}{l}6.67 \\
\pm \\
0.08\end{array}$ & $\begin{array}{l}6.75 \\
\pm \\
0.08\end{array}$ & $\begin{array}{ll}6.77 & \pm \\
0.01 & \end{array}$ & $\begin{array}{l}6.99 \\
\pm \\
0.18\end{array}$ \\
\hline $\begin{array}{l}\text { Organic } \\
\text { matter (\%) }\end{array}$ & $\begin{array}{ll}4.06 \pm \\
0.13\end{array}$ & $\begin{array}{l}9.69 \\
\pm \\
0.27\end{array}$ & $\begin{array}{l}10.5 \\
4 \quad \pm \\
0.11\end{array}$ & $\begin{array}{l}14.84 \\
\pm \\
0.13\end{array}$ & $\begin{array}{l}15.95 \pm \\
0.32\end{array}$ & $\begin{array}{l}16.4 \\
3 \quad \pm \\
2.05\end{array}$ \\
\hline $\begin{array}{l}\text { Organic } \\
\text { carbon (\%) }\end{array}$ & $\begin{array}{l}2.55 \pm \\
0.01\end{array}$ & $\begin{array}{l}4.84 \\
\pm \\
0.01\end{array}$ & $\begin{array}{l}5.70 \\
\pm \\
0.01\end{array}$ & $\begin{array}{l}\text { 6.77 } \\
\pm \\
0.02\end{array}$ & $\begin{array}{ll}7.21 \quad \pm \\
0.01 & \end{array}$ & $\begin{array}{l}8.60 \\
\pm \\
0.03\end{array}$ \\
\hline $\begin{array}{l}\text { CEC } \\
(\mathrm{meq} / 100 \mathrm{~g})\end{array}$ & $\begin{array}{l}8.34 \pm \\
0.07\end{array}$ & $\begin{array}{l}11.5 \\
3 \quad \pm \\
0.05\end{array}$ & $\begin{array}{l}15.7 \\
0 \quad \pm \\
0.04\end{array}$ & $\begin{array}{l}17.81 \\
\pm \\
0.07\end{array}$ & $\begin{array}{l}18.84 \pm \\
0.03\end{array}$ & $\begin{array}{l}18.9 \\
6 \quad \pm \\
0.04\end{array}$ \\
\hline $\begin{array}{l}\text { Nitrogen } \\
\text { (\%) }\end{array}$ & $\begin{array}{ll}0.11 \quad \pm \\
0.00\end{array}$ & $\begin{array}{l}0.20 \\
\pm \\
0.01\end{array}$ & $\begin{array}{l}0.27 \\
\pm \\
0.01\end{array}$ & $\begin{array}{l}0.32 \\
\pm \\
0.003\end{array}$ & $\begin{array}{ll}0.44 & \pm \\
0.02 & \end{array}$ & $\begin{array}{l}0.50 \\
\pm \\
0.01\end{array}$ \\
\hline $\begin{array}{l}\text { Phosphorou } \\
\mathrm{s}(\mathrm{mg} / \mathrm{kg})\end{array}$ & $\begin{array}{l}22.99 \pm \\
0.86\end{array}$ & $\begin{array}{l}33.0 \\
8 \quad \pm \\
2.88\end{array}$ & $\begin{array}{l}54.1 \\
3 \quad \pm \\
3.25\end{array}$ & $\begin{array}{l}70.82 \\
\pm \\
2.36\end{array}$ & $\begin{array}{l}74.27 \pm \\
1.55\end{array}$ & $\begin{array}{l}78.1 \\
5 \quad \pm \\
1.68\end{array}$ \\
\hline $\begin{array}{l}\text { Manganese } \\
(\mathrm{mg} / \mathrm{kg})\end{array}$ & $\begin{array}{ll}7.47 \quad \pm \\
0.15\end{array}$ & $\begin{array}{l}7.92 \\
\pm \\
0.08\end{array}$ & $\begin{array}{l}8.14 \\
\pm \\
0.10\end{array}$ & $\begin{array}{l}8.81 \\
\pm \\
0.09\end{array}$ & $\begin{array}{ll}9.81 \quad \pm \\
0.55 & \end{array}$ & $\begin{array}{l}8.94 \\
\pm \\
0.04\end{array}$ \\
\hline
\end{tabular}

Further, there was increase in organic carbon from $2.55 \pm 0.01 \%$ to a maximum of $8.65 \pm$ $0.03 \%$ at $25 \%$ SSB amendment which may be due to the presence of compostable wastes generated within the soils [51]. Similarly, organic matter increased from $2.50 \pm 0.04 \%$ in the fresh soils to $16.43 \pm 2.05 \%$ for $25 \% \mathrm{SSB}$ amended soils. Amendment led to increase in organic matter probably due to the decomposition of wastes generated within the soils. Similar observations were previously reported when poultry droppings were used for amendment of CCA contaminated soils [52].

Further, CEC was from $6.80 \pm 0.32 \mathrm{meq} / 100 \mathrm{~g}$ in the fresh soils to $18.96 \pm 0.04 \mathrm{meq} / 100 \mathrm{~g}$ for $25 \%$ SSB amended soils. CEC of soils varies according to the soil type and \% Clay, $\mathrm{pH}$ and organic matter [50], and since some of these parameters increased, CEC also increased. Increase in CEC is a favourable phenomenon in phytoremediation as it means reduced solubility of metals, keeping the plants active to perform perfect pollutant clean up [52]. Similarly, nitrogen and phosphorous content increased, probably due to the decomposition of the SSB used for amendment. However, manganese reduced significantly in both the control and amended soils. These could have been due to them being fixed into insoluble fractions of the soil.

\section{Metal accumulation in plant tissues and soils}

Plants possess different potencies to accumulate and detoxify heavy metals $[20,53]$. In this study, heavy metal accumulation in the maize tissues and soils differed for the three heavy metals 
(Figure 1). Chromium had the highest concentration in the roots, shoots and soils at different amendments and there were significant differences $(p \leq 0.05)$ between $\mathrm{Cr}$ concentrations in the plant tissues and the soils. The accumulation followed the sequence shoot $>$ root $>$ soil. The highest chromium concentrations $(193.80 \pm 0.03,192.40 \pm 0.40$ and $10.10 \pm 0.04$ $\mathrm{mg} / \mathrm{kg}$ in the shoot, roots and soils respectively) were recorded in the control pot. On the other hand, copper was moderately accumulated in maize shoots and roots and the soils. This could be due to the increase in phosphorous content with amendment. Phosphorous-based materials have reputation as metal fixing agents in the soil, typically by direct adsorption through phosphate, phosphate-anion-induced metal adsorption and precipitation of metals as phosphates. Contingent on the source, addition of phosphates to the soil can cause direct adsorption through increased surface charge and enhanced anion-induced metal adsorption $[54,55]$. On the other hand, much $(p \leq 0.05)$ of the arsenic remained in the unamended soils compared to those in amended soils. This could have been due to ion exchange, which increases arsenic mobility in soils.

The results of this study agreed with previous observations $[20,56]$ that plants may effectively but selectively act as accumulators and indicators. The total concentrations of $\mathrm{Cr}$ and $\mathrm{Cu}$ in the roots and shoots did not correlate with those in the soils. This finding therefore is in complete agreement with previous observations that total metal concentration is a weak predictor of metal availability for plants [33, 57]. The differences in heavy metal uptake by the maize plants could have been due to synergistic influence of factors such as soil $\mathrm{pH}, \mathrm{CEC}$, organic matter content and the presence of other ions $[57,58]$. Taken together, these findings indicate that MM3 maize variety has varying remediative potential for each heavy metal in CCA contaminated soils and may be selectively used for phytoextraction of $\mathrm{Cr}, \mathrm{Cu}$ and $\mathrm{As}$ from CCA contaminated soils without or with $5-25 \%$ SSB amendments.

Phytoremediation efficiency of the maize plants

The ability of maize plants to accumulate trace metals from the CCA contaminated soils was evaluated using BAF and TF. The criterion used was that if $\mathrm{BAF}_{\text {shoot }}>1$, then the plants would be accumulators, while plants with $\mathrm{BAF}_{\text {shoot values }}$ $<1$ are excluders [56]. Additionally, plants would be classified as potential hyperaccumulators if the $\mathrm{BAF}_{\text {shoot }}$ values were $>10$ [34]. Our computation (Table 4) showed that MM3 maize variety had $\mathrm{BAF}_{\text {shoot }}>1$ for $\mathrm{Cr}$ and $\mathrm{Cu}$ for all the potted soils. For arsenic, the values were less than 1 in control and 5\% SSB amended soils. It is known that the success of phytoextraction is contingent on heavy metal removal by the shoots [20]. Thus, the results of this study suggests that the maize variety have the potential to be used as an hyperaccumulator of $\mathrm{Cr}$ without or with $5 \%$ amendment. It could 
also be used as an accumulator of $\mathrm{Cu}$ with or amendment and arsenic with $10-25 \%$ SSB without amendment, for $\mathrm{Cr}$ with $10-25 \%$ amendment.

Table 4. Bioaccumulation factor and translocation factor of the maize plants in the control and amended soils.

\begin{tabular}{|c|c|c|c|c|c|c|c|c|c|}
\hline \multirow{2}{*}{ Pot } & \multicolumn{3}{|c|}{$\mathrm{BAF}_{\text {shoot }}$} & \multicolumn{3}{c|}{$\mathrm{BAF}_{\text {root }}$} & \multicolumn{3}{c|}{$\mathrm{TF}$} \\
\cline { 2 - 10 } & $\mathrm{Cr}$ & $\mathrm{Cu}$ & $\mathrm{As}$ & $\mathrm{Cr}$ & $\mathrm{Cu}$ & $\mathrm{As}$ & $\mathrm{Cr}$ & $\mathrm{Cu}$ & $\mathrm{As}$ \\
\hline $\mathrm{Ctrl}$ & 19.19 & 1.76 & 0.09 & 19.05 & 1.41 & 0.09 & 1.01 & 1.25 & 1.00 \\
\hline $5 \%$ & 11.47 & 3.85 & 0.80 & 10.77 & 4.51 & 2.74 & 1.07 & 0.85 & 0.29 \\
\hline $10 \%$ & 9.18 & 2.59 & 1.71 & 9.17 & 3.40 & 1.71 & 1.00 & 0.76 & 1.00 \\
\hline $15 \%$ & 8.61 & 1.25 & 1.59 & 8.66 & 2.56 & 1.60 & 0.99 & 1.29 & 0.99 \\
\hline $20 \%$ & 8.20 & 4.02 & 1.59 & 8.27 & 2.68 & 1.58 & 0.99 & 1.25 & 1.01 \\
\hline $25 \%$ & 6.81 & 6.85 & 1.43 & 6.86 & 5.69 & 1.56 & 0.99 & 1.20 & 0.92 \\
\hline
\end{tabular}

Conversely, $\mathrm{BAF}_{\text {root }}$ values of $>1$ indicate high efficacy in the phytostabilization of the heavy metal-contaminated soils. $\mathrm{Cr}$ and $\mathrm{Cu}$ had bioaccumulation factors in the roots greater than 1 in all the potted soils, and thus the maize variety could be used for phytostabilization of $\mathrm{Cr}$ and $\mathrm{Cu}$ in the CCA contaminated soils. Arsenic could however only be phytostabilized with 5-25\% SSB amendment.

The TF has been used to characterize the phytoremediation potential of plants $[20,33,56$, 59]. A plant with TF $>1$ is classified as a highefficiency plant for a specific metal translocation from the roots to shoots [34]. In this study, the $\mathrm{TF}$ for $\mathrm{Cr}$ reduced with increase in SSB amendment before increasing again at 25\% amendment, corroborating a previous observation [60]. All the heavy metals had TF equal to or greater than 1 in pots without amendment. This implied that the maize variety could be used to phytoextract them from unamended CCA contaminated soils.
Phytoextraction of $\mathrm{Cr}$ would also be effective in soils amended with $5-10 \%(w / w)$ of SSB while for copper would be feasible with $15-25 \%$ SSB amendment. On the other hand, arsenic could also be phytoextracted with $10 \%$ or $20 \% \mathrm{SSB}$ amendment of the contaminated soils.

Computation of the pollution indices (PI and IPI) for the soils after 80 days of phytoremediation (Table 5) showed that the contamination levels of the soils following phytoremediation were low.

Table 5. Pollution indices of the CCA contaminated soils after 80 days of planting.

\begin{tabular}{|c|c|c|c|c|c|c|}
\hline \multirow{2}{*}{ Metal } & \multicolumn{7}{|c|}{ Pollution index } \\
\cline { 2 - 7 } & Ctrl & $5 \%$ & $10 \%$ & $15 \%$ & $20 \%$ & $25 \%$ \\
\hline $\mathrm{Cr}$ & 0.15 & 0.25 & 0.29 & 0.31 & 0.32 & 0.38 \\
\hline $\mathrm{Cu}$ & 1.18 & 0.53 & 0.71 & 0.72 & 0.60 & 0.37 \\
\hline $\mathrm{As}$ & 4.66 & 1.28 & 1.28 & 1.35 & 1.35 & 1.40 \\
\hline $\mathrm{IPI}$ & 2.00 & 0.69 & 0.43 & 0.79 & 0.76 & 0.72 \\
\hline
\end{tabular}

Ctrl: Control.

Copper in amended soils and arsenic had pollution indices $1<\mathrm{PI}<3$ and $\mathrm{PI} \geq 3$ which corresponds to moderate and high respectively. 
Further only the control soils had IPI $>2$ which corresponds to high pollution. Thus, MM3 maize variety reduced drastically the pollution levels of the soils.

\section{Conclusion}

This study has shown that MM3 maize variety could be used to selectively phytoextract copper and arsenic from CCA contaminated soils, without or with $5-20 \%(\mathrm{w} / \mathrm{w})$ sewage sludge biosolid amendment. Further studies should use other maize varieties such as Longe hybrid maize varieties commonly grown in Uganda. These varieties can take up to 120 days before maturity which could make them good phytoremediators. The mobility of the metals in the different fractions of the contaminated soils should be investigated.

\section{Acknowledgements}

The authors are grateful to DAAD and Mbarara University of Science and Technology for the scholarship and support given to CKN which gave birth to this communication. Sincere thanks to the Management of Kitetika Wood Factory, National Water and Sewerage Corporation, FICA Seeds Limited, and Directorate of Government Analytical Laboratory (DGAL), Uganda for the resources and services generously accorded that made this research a success.

\section{References}

[1] Ramage $\mathrm{MH}$, Burridge $\mathrm{H}$, Busse-Wicher $\mathrm{M}$, Fereday G, Reynolds T, Shah DU et al. The wood from the trees: The use of timber in construction. Renew Sust Energ Rev. 2017; 68(1): 333-59.

[2] Larry L. The advantages of wood as a building material. 2019. Retrieved from https://www.wagnermeters.com/moisturemeters/wood-info/advantages-wood-building/.

[3] Turyahabwe N, Kakuru W, Asiimwe M, Byakagaba P. Proximate and Underlying Causes of Illegal Timber Trade in Uganda, Precious Forests Precious Earth, Miodrag Zlatic, IntechOpen. 2015. pp. $3-20$.

[4] Josephat M. Deforestation in Uganda: population increase, forests loss and climate change. Environ Risk Assess Remed. 2018; 2(2): 46-50.

[5] Walakira P, Okot-Okumu J. Impact of industrial effluents on water quality of streams in NakawaNtinda, Uganda. J Appl Sci Environ Manage. 2011; 15(2): 289-296.

[6] Omara T, Othieno N, Obonge J, Ssebulime S, Kansiime M. Characterization and prognostication of wastes generated by industries in Kampala Industrial and Business Park-Namanve. OALib J. 2019; 6(1): e5189.

[7] Nakiguli CK, Namakula B, Odda J, Wasswa J, Ntambi E. Heavy Metal Accumulation in Maize (Zea mays L.) Grown on Chromated Copper Arsenate (CCA) Contaminated Soil Amended with Treated Composted Sewage Biosolid. J Environ Protect. 2018; 9: 1196-1204.

[8] Robey NM, Solo-Gabriele HM, Jones AS, Marini J, Townsend TG. Metals content of recycled construction and demolition wood before and after implementation of best management practices. Environ Pollut. 2018; 242: 1198-1205.

[9] Jones AS, Marini J, Solo-Gabriele HM, Robey NM, Townsend TG. Arsenic, copper, and chromium from treated wood products in the U.S. disposal sector. Waste Manage. 2019; 87: 731-40.

[10] Coles CA, Arisi JA, Organ M, Veinott GI. Leaching of chromium, copper, and arsenic from CCA- 
treated utility poles. Appl Environ Soil Sci. 2014; 2014: 167971.

[11] Oh J, Kim G. The effects of $\mathrm{pH}$ on copper leaching from wood treated with copper amine-based preservatives. Holzforschung. 2020; 20190218. doi: 10.1515/hf-2019-0218.

[12] Kamchanawong S, Veerakajohnsak C. Arsenic, chromium, and copper leaching from CCA-treated wood and their potential impacts on landfill leachate in a tropical country. Environ Technol. 2010; 31(4): 381394.

[13] Khan BI, Solo-Gabriele HM, Townsend TG, Cai Y. Release of arsenic to the environment from CCAtreated wood. 1. Leaching and speciation during service. Environ Sci Technol. 2006;40(3):988-993.

[14] Khan BI, Jambeck J, Solo-Gabriele HM, Townsend TG, Cai Y. Release of arsenic to the environment from CCA-treated wood 2. Leaching and speciation during disposal. Environ Sci Technol. 2006;40(3): 994-999.

[15] Song J, Dubey B, Jang Y, Townsend TG, SoloGabriele HM. Implication of chromium speciation on disposal of discarded CCA-treated wood. J Hazard Mat. 2006;128(2-3):280-288.

[16] Nico PS, Fendorf SE, Lowney YW, Holm SE, Ruby MV. Chemical structure of arsenic and chromium in CCA-treated wood: Implications of environmental weathering. Environ Sci Technol. 2004; 38(19): 52535260.

[17] Vera VP, Cuevas UE, Cortes A. Optimization of a quality model for CCA industrial impregnation of Pinus radiate D. Don agricultural fencing stakes. Wood Res. 2013; 58(1):131-140.

[18] Dawson BSW, Parker GF, Cowan FJ, Hong SO. Interlaboratory determination of copper, chromium, and arsenic in timber treated with preservative. Analyst. 1991; 16(4):339-346.

[19] Kim H, Kim DJ, Koo JH, Park JG, Jang YC. Distribution and mobility of chromium, copper, and arsenic in soils collected near CCA-treated wood structures in Korea. Sci Total Environ. 2007; 374(2-3): 273-281.

[20] Usman ARA, Lee SS, Awad YM, Lim KJ, Yang JE, Ok YS. Soil pollution assessment and identification of hyperaccumulating plants in chromated copper arsenate (CCA) contaminated sites, Korea. Chemosphere. 2012; 87(8): 872-878.

[21] Nakiguli CK, Ojok W, Omara T, Wasswa J, Ntambi E. Mobility of Chromium, Copper and Arsenic in Amended Chromated Copper Arsenate Contaminated Soils. Asian J Appl Chem Res. 2020; 6(4): 33-48.

[22] Saxe JK, Bowers TS, Reid KR. Arsenic in Environmental Forensics-Contaminant Specific Guide, Academic Press. 1964. pp. 279-292.

[23] Katz SA, Salem H. Chemistry and toxicology of building timbers pressure-treated with chromated copper arsenate: a review. J Appl Toxicol. 2005; 25(1):1-7.

[24] Okalebo JR, Gathua KW, Woomer PL. Laboratory methods of soil and plant analyst working manual unpublished report 2nd edition RSBF-CIAT and Sacred Africa Nairobi, Kenya, 2002. 131p.

[25] Page AL, Miller RH, Keeney DR. Ed 2 Part II. Methods of Soil Analysis. Madison, WI American Society of Agrononomy. 1982. 803p.

[26] Tessier A, Campbell PGC, Bisson M. Sequential extraction procedures for the speciation of particulate trace metals. Anal Chem. 1979; 51(7): 844-851.

[27] Omara T, Nteziyaremye P, Akaganyira S, Opio DW, Karanja LN, Nyangena DM et al. Physicochemical quality of water and health risks associated with consumption of African lung fish (Protopterus annectens) from Nyabarongo and Nyabugogo rivers, Rwanda. BMC Res Notes. 2020; 13(1): 66 .

[28] Nteziyaremye P, Omara T. Bioaccumulation of priority trace metals in edible muscles of West African lungfish (Protopterus annectens Owen, 1839) from 
Nyabarongo River, Rwanda. Cogent Environ Sci. 2020; 6(1): 1779557.

[29] Omara T, Ogwang R, Ndyamuhaki S, Kagoya S, Kigenyi E, Musau B, Adupa E. Spectroscopic analysis of selected priority trace metals in the extant East African gilled lungfish (Protopterus amphibius) in Lira municipal lagoon and its edibility health risk. Sci J Anal Chem. 2018;6(5):38-45.

[30] Omara T, Karungi S, Kalukusu R, Nakabuye BV, Kagoya S, Musau B. Mercuric pollution of surface water, superficial sediments, Nile Tilapia (Oreochromis nilotica Linnaeus 1758 [Cichlidae]) and yams (Dioscorea alata) in auriferous areas of Namukombe stream, Syanyonja, Busia, Uganda. PeerJ. 2019; 7: e7919.

[31] Callender E. Heavy metals in the environmentHistorical trends. In: Lollar, B.S. (Ed.), Environmental Geochemistry. Treatise Geochem. 2003; 9: 67-105.

[32] Reimann C, Garrett RG. Geochemical background-concept and reality. Sci Total Environ. 2005; 350(1-3): 12-27.

[33] Yoon J, Cao X, Zhou Q, Ma LQ. Accumulation of $\mathrm{Pb}, \mathrm{Cu}$, and $\mathrm{Zn}$ in native plants growing on a contaminated Florida site. Sci Total Environ. 2006; 368(2-3): 456-464.

[34] Ma LQ, Komar KM, Tu C, Zhang W, Cai Y, Kennelley ED. A fern that hyperaccumulates arsenic. Nature. 2001; 409(579): 1.

[35] Nyle CB, Ray RW. Nature and properties of soils. 3rd edition, vol. 663. 2005. pp. 33-34.

[36] Tsetimi GO, Okieimen FE. Chelate-assisted phytoextraction of metals from chromated copper arsenate (CCA) contaminated soil. J Environ Chem Ecotoxicol. 2011; 3(8): 214-224.

[37] Hazelton PA, Murphy BW. Interpreting Soil Test Results: What Do All The Numbers Mean?. CSIRO Publishing: Melbourne. 2007.

[38] Smith SR. Organic contaminants in sewage sludge (biosolids) and their significance for agricultural recycling. Philos Trans A Math Phys Eng Sci. 2009; 367: 4005-4041.

[39] Nelson DW, Sommers LE. Total Carbon, Organic Carbon, and Organic Matter. In: Methods of Soil Analysis, Part 2. Chemical and Microbiological Properties-Agronomy Monograph no. 9 (2nd Edn). 1982. pp. 539-579.

[40] Temiz A, Yildiz UC, Nilsson T. Comparison of copper emission rates from wood treated with different preservatives to the environment. Build Environ. 2006; 41 (7): 910-914.

[41] Kartal SN, Hwang WJ, Imamura Y. Evaluation of effect of leaching medium on the release of copper, chromium, and arsenic from treated wood. Build Environ. 2007; 42(3): 1188-1193.

[42] Jang YC, Townsend TG, Ward M, Bitton G. Leaching of arsenic, chromium, and copper in a contaminated soil at a wood preserving site. Bull Environ Contam Toxicol. 2002; 69: 808-16.

[43] Zagury GJ, Samson R, Deschenes L. Occurrence of metals in soil and ground water near chromated copper arsenate-treated utility poles. J Environ Qual. 2003; 32: 507-514.

[44] Robinson B, Greven M, Green S, Sivakumaran S, Davidson P, Clothier B. Leaching of copper, chromium, and arsenic from treated vineyard posts in Marlnorough, New Zealand. Sci Total Environ. 2006; 364(1-3): 113-123.

[45] Stilwell DE, Gorny KD. Contamination of soil with copper, chromium, and arsenic under decks built from pressure treated wood. Bull Environ Contam Toxicol. 1997; 58: 22-29.

[46] Gress J, de Oliveira LM, da Silva EB, Lessl, JM, Wilson PC, Townsend T, Ma LQ. Cleaning-induced arsenic mobilization and chromium oxidation from CCA-wood deck: potential risk to children. Environ Int. $2015 ; 82: 35-40$.

[47] Toth G, Hermann T, DaSilva MR, Montanarella

L. Heavy metals in agricultural soils of the European 
Union with implications for food safety. Environ Int. 2016; 88: 299-309.

[48] UNEP. Environmental risks and challenges of anthropogenic metals flows and cycles. In: E. vander Voet, R. Salminen, M. Eckelman, G. Mudd, T. Norgate, R. Hischier (Eds). A Report. 2013.

[49] Tokalioğlu S, Kavtal S, Gultekin A. Investigation of heavy metal uptake by vegetables growing in contaminated soil using the modified BCR sequential extraction method. Int J Environ Anal Chem. 2006; 88(06): 417-430.

[50] Brown SL, Chaney RL, Angle JS, Baker AM. Zinc and cadmium uptake by hyperaccumulator Thlaspicaerulescens and metal tolerant Silene vulgaris grown on sludge amended soils. Environ Sci Technol. 1995. 29(6): 1581-1585.

[51] Munoz M, Pena L, Halloroms JO. Use of an industrial by product as liming source. J Agric Univ Puerto Rico. 1994; 78(3-4): 73-86.

[52] Ikhuoria EU, Urunmatsoma SOP, Okieimen FE. Preliminary investigation of chemical fractionation and heavy metal accumulation in plant maize (Zea mays) grown on chromated copper arsenate contaminated soil amended with poultry droppings. Afr J Biotechnol. 2010; 9(8): 2675-82.

[53] Lee SB, Lee YB, Lee CH, Hong CO, Kim PJ, Yu C. Characteristics of boron accumulation by fly ash application in paddy soil. Biores Technol. 2008; 99(13): 5928-32.

[54] Mc Gowen SL, Basta NT, Brown GO. Use of diammonium phosphate to reduce heavy metal solubility and transport in smelter-contaminated soil. J Environ Qual. 2001; 30(2): 493-500.

[55] Raicevic S, Kaludjerovic-Radoicic T, Zouboulis AI. In situ stabilization of toxic metals in polluted soils using phosphates: theoretical prediction and experimental verification. J Hazard Mat. 2005; 117(1): 41-53.
[56] Baker AJM. Accumulators and excluderstrategies in the response of plants to heavy metals. $J$ Plant Nutr. 1981; 3(1-4): 643-54.

[57] Kabata-Pendias A, Pendias H. Trace Elements in Soils and Plants, second ed. CRC Press Inc., Boca Raton, Florida. 1992.

[58] Jung K, Ok YS, Chang SX. Sulfate adsorption properties of acid-sensitive soils in Athabasca oil sands region in Alberta, Canada. Chemosphere. 2011; 84(4): 457-63.

[59] Srivastava M, Ma LQ, Santos JAG. Three new arsenic hyperaccumulating ferns. Sci Total Environ. 2006; 364(1-3): 24-31.

[60] Gul S, Naz A, Khan A, Nisa S, Irshad M. Phytoavailability and Leachability of Heavy Metals from Contaminated Soil Treated with Composted Livestock Manure. Soil Sediment Contam. 2016; 25(2): 181-194. 